\title{
PHLPP2 wt Allele
}

National Cancer Institute

\section{Source}

National Cancer Institute. PHLPP2 wt Allele. NCI Thesaurus. Code C107126.

Human PHLPP2 wild-type allele is located in the vicinity of $16 q 22.2$ and is approximately $87 \mathrm{~kb}$ in length. This allele, which encodes $\mathrm{PH}$ domain leucine-rich repeat-containing protein phosphatase 2 protein, plays a role in the regulation of apoptosis and may act as a tumor suppressor. 